\title{
Analytical Review of e-Learning in the State of Qatar
}

\author{
Alan S. Weber
}

\begin{abstract}
This contribution provides a comprehensive analytical overview of e-learning in the State of Qatar. A systematic review of the peer-reviewed literature was carried out in Sciverse, Web of Knowledge, IEEE Xplore, Proquest, SpringerLink, and Google Scholar. Government reports and white papers were additionally obtained from the Internet regulatory agency ictQatar. The history, development, and current state of e-learning as well as related e-services such as e-governance are presented in an analytical narrative. In addition to providing a valuable case study of technological advancement in a developing nation in the Middle East, the topic is of great interest internationally due to Qatar's national development strategy to diversify its resource-based economy to include education, training, and ICT research and development Lessons learned from Qatar's e-learning initiatives and investments in communications infrastructure (Ooredoo) and cybersecurity (Q-Cert) are instructive for other developing nations, in particular Muslim-majority and Arab-speaking nations since several key cultural and social factors in e-learning services provision are being actively resolved by the State of Qatar.
\end{abstract}

Index Terms-E-learning, Qatar, distance education-State of Qatar, e-governance, knowledge economy.

\section{INTRODUCTION}

The State of Qatar lies on the eastern end of the Arabian Peninsula bordering on Saudi Arabia with its closest neighbors being Bahrain and United Arab Emirates. The peninsula of Qatar lies on the opposite shore of Iran, which shares with Qatar one of the largest non-associated gas fields in the world, the North Dome / South Pars field. Consequently, much of Qatar's export revenue as well as government revenue (from State Owned Enterprises, such as Qatar Petroleum and Public Private Partnerships such as Qatargas, the largest Liquefied Natural Gas company in the world) derives from the production of gas and oil. Qatar is the largest exporter of Liquefied Natural Gas in the world and ranks $14^{\text {th }}$ in world oil production. Surplus hydrocarbon revenues from the 1990s to mid-2000s were invested in a Sovereign Wealth Fund and also used to improve basic infrastructure such as roads, airports, ports, and public services [1].

The Qatar peninsula is arid with minimal rainfall and plant cover consisting of a few species of trees and shrubs, drought

Manuscript received October 25, 2016; revised February 12, 2017. This work was supported in part by Qatar Foundation for Education, Science and Community Development and Weill Cornell Medicine - Qatar. The author has no financial, research or personal conflicts of interest related to this research. No human or animal subjects were used in this research. The views expressed are those of the author and not necessarily those of Weill Cornell Medicine - Qatar or Cornell University.

Alan S. Weber is with the Premedical Department of Weill Cornell Medicine, Qatar (e-mail: alw2010@qatar-med.cornell.edu, tel. +9744492 8220 , fax +97444928200$)$. resistant plants and ephemeral grasses. Due to scarce rain and lack of forage, the country was mainly visited by nomadic pastoralists $(b e d d u)$ in the winter, with some permanent settlements on the coast supported by wells. Coastal Arabs (hadar) engaged in fishing, the pearl trade and shipping, and trading with Iran and India to supply the Arabs of Eastern Arabia with goods such as wood, flour, textiles, and spices. A portion of Qatar's population originated in Africa and were brought to Qatar via the Omani slave trade in Zanzibar mainly to man the large pearling fleet in the late $19^{\text {th }}$ and early $20^{\text {th }}$ century. Slavery was abolished in Qatar in 1952.

An hereditary Emir from the Al Thani family, the family that signed the maritime truce with Britain's political agent Lewis Pelly in 1868, rules the country, which adopted a new constitution by an overwhelming majority in 2004-2005. An elected Shura (advisory) council has been promised but has not materialized. One of the main functions of the government is to distribute oil wealth equitably. Qataris therefore enjoy many free services, including education from kindergarten through tertiary education, with options to study abroad [2].

Most Qataris, who number approximately 300,000, are Sunni Muslims, with a small Shia population that does not practice publicly (such as celebrating ashura) due to current negative attitudes towards Shia-majority Iran. Both Iran and Qatar jointly exploit the North Dome Field / South Pars Field natural gas condensate field, the world's largest natural gas reservoir which runs under the Persian Gulf between the two countries. Qataris make up only approximately $10 \%$ of the total population, with the remainder consisting of foreign expatriate workers on short-term contracts who work in the service, construction, transportation and oil industries.

Many of these expatriate workers are males who have arrived without their families and who send substantial amounts of remittance wages back to their home countries of Nepal, Bangladesh, Philippines, Egypt and Sri Lanka; thus Qatar has one of the highest male to female ratios in the world at 4.91 for ages 25-54 [3]. Workers in the construction and services industry are paid minimal wages and have limited access to the Internet. Although the Qatari government is developing programs to expand access to all users (inclusion policies), high cost and limited access are serious barriers to the potential use of e-learning to improve the lives of manual laborers by providing them with basic health, banking, and legal informational modules to protect their health and basic rights. Qatar has been criticized for labor abuses in the international press, and in response began providing e-services to manual laborers, such as electronic payments of wages, which were not common in Qatar's cash economy. Electronic payment allows the government to monitor non-payment of wages, a serious problem in the construction industry, and in 2016, the labor ministry reported a decrease in complaints of 30.4 percent, with only 2,676 worker 
complaints in 2016 compared to 3,845 for the same period in 2015 [4].

\section{EDUCATION IN THE STATE OF QATAR}

Schooling was limited in the era before 1948 when oil wealth was used to build a modern school system that began to mature in the late 1950 s and early 1960 s. In the entire Al Ahsa region (Eastern Arabian area), there were only 20 kuttab (religious schools) for children and 30 madrasah for adults teaching Arabic and Quranic sciences in the period 1878 - 1913 [5]. Many Qataris were therefore illiterate until mid-century. Thus the evolution from an almost non-existent schooling system to modern technology-based classrooms at the secondary and tertiary level is astounding and occurred within only 2 generations.

The traditional schools used memorization as a primary pedagogical tool, a practice that continues to impact education in Qatar to this day. One challenge of non-blended purely online learning in Qatar today is that it presupposes an autonomous learner paradigm common in Western countries, whereas the traditional Arabic educational methods place more emphasis on the teacher as the locus of authority. Girls were educated as well as boys in separate kuttabs, such as Aminah Mahmud's school, which became the first girls' school in Qatar in 1954.

Qatar has one national university, Qatar University, opened in 1977, and the country began to internationalize its higher education system in the mid 1990s. In 1995, HH Sheikh Hamad bin Khalifa Al Thani, the Father Emir of Qatar (former Emir) and his wife HH Sheikha Mozah bint Nasser founded Qatar Foundation and invited a group of American universities to set up branch campuses in $\mathrm{Al}$ Rayyan outside of Doha in an educational complex called Education City. The following bachelor-degree granting satellite campuses were established: Virginia Commonwealth University in Qatar (Arts and Design - 1998), Weill Cornell Medical College in Qatar (Medicine - 2002), Texas A\&M University at Qatar (Engineering - 2003), Carnegie Mellon University in Qatar (Computer Science and Business - 2002), Georgetown School of Foreign Service in Qatar (Foreign Service - 2005), and Northwestern University (Communications and Journalism - 2008). A locally-developed institution, The Qatar Faculty of Islamic Studies (Islamic Studies, Islamic Finance, and Islamic Public Policy - 2007) joined Education City in 2007. HEC Paris, one the world's most prestigious business schools, opened its business program in 2011 to complement the Dutch business college Stenden University (not located in Education City). The University College London in Qatar campus was the last institution to join, providing masters degrees in Museum and Gallery Practice and Library and Information Studies [6].

In addition to higher education reforms, Education for a New Era (ENFE) was inaugurated in 2001-2 introducing sweeping changes in the K-12 system. The programs were developed by the U.S. RAND Corporation and included reforms in curricula and teacher training, assessment and professional development. The programs were modeled on American-style educational paradigms. Technology and e-learning were built into many of the assumptions of EFNE in that student activities would presuppose innovations such as flipped classrooms and rapid access to information to complete school projects.

The Qatar National Vision 2030 (QNV 2030) was launched in 2008 by the General Secretariat for Development Planning (GSDP) under Secretary General HH Dr. Ibrahim Ibrahim, who reported directly to the Heir Apparent Sheikh Tamim Bin Hamad Al Thani, currently serving as the Emir of Qatar after his father's voluntary abdication in 2013. The QNV 2030 was a national development blueprint for creating a modern, prosperous, highly developed, technology-based, and well-educated nation. According to QNV 2030, “Qatar National Vision 2030 builds a bridge between the present and the future. It envisages a vibrant and prosperous country in which there is economic and social justice for all, and in which nature and man are in harmony. We need to galvanize our collective energies and direct them toward these aspirations. Strong Islamic and family values will provide our moral and ethical compass" [7]. The vision statement mentions several times the importance of traditional Qatari values, signaling a certain discomfort with rapid change and shifts in behavior that have accompanied the rapid adoption of cell phone, tablet and laptop use by youth, such as the danger of potentially making contact with members of the opposite sex. Qatari society still practices gender segregation and most marriages continue to be arranged by parents.

Many Qataris work in the public sector as clerks or managers in government offices, and government leaders are attempting to move more Qataris into the private sector and encourage entrepreneurship since the public sector is very inefficient due to the general expectation that the government should guarantee high salaries, benefits, and flexible and minimal work hours. Thus the QNV 2030 explicitly encourages education and training for Qatar's entry into the competitive global economy. As the QNV 2030 points out: "Future economic success will increasingly depend on the ability of the Qatari people to deal with a new international order that is knowledge-based and extremely competitive. To meet the challenge, Qatar is establishing advanced educational and health systems, as well as increasing the effective participation of Qataris in the labor force" [8].

The GSDP issued another more detailed planning document, The Qatar National Development Strategy 2011-2016 (QNDS), in 2011. The QNDS emphasizes the importance of ICT in learning for both teachers and students: "Information and communication technology (ICT) is a key enabler of successful education and training. Mastery of technology is required to participate in and contribute more effectively to the knowledge economy. Using ICT in teaching can improve learning outcomes and increase effectiveness in administrative functions" [9]. In order to achieve an integrated ICT plan for Qatar's education sector, the government pledges to:

- Develop an integrated ICT strategy for all education sectors in Qatar based on international ICT best practices to improve management, administrative processes, learning environments, teaching methods and education outcomes.

- Prepare a detailed implementation plan for increased ICT use in school administration and in education services 
delivery, along with a set of ICT standards that are mandatory for public education institutions and strongly recommended for private institutions [10].

Thus integrating all aspects of best practices computerassisted learning including e-learning into society and educational institutions was set as a specific development target for the State of Qatar by the highest levels of government.

\section{E-LEARNING INITIATIVES}

The first e-learning initiatives in Qatar were developed in Education City among the U.S. satellite campuses. For example, the new building of Weill Cornell Medical College Qatar (name changed to Weill Cornell Medicine - Qatar) has been equipped with completely online and blended resources since its inception in 2002-3. Due to shortages of specialty faculty to teach highly technical courses, live video feed courses are run from the main campus in New York City. One course, Psychology 101, is taught by recorded lecture from the Ithaca, New York campus while a Teaching Assistant in Doha manages the Qatar classroom and responds to questions and administers exams. With the availability of low or free cost VoIP suites and videoconferencing software such as Skype or Facetime all higher education institutions in Qatar have some teleconferencing capabilities, with WCM-Q, Georgetown SFS - Qatar, and Texas A \& M - Qatar having fully equipped state-of-the art teleconferencing theatres.

In K-12 education, the earliest e-learning initiatives were K-Net and e-schoolbag implemented by ictQatar and Infocomm Development Authority of Singapore (IDA). E-schoolbag was launched as a pilot project at Al Wakrah Independent School for Girls in 2006. Over two hundred $7^{\text {th }}$ grade students received Tablet PCs with "e-contents on science, maths, and English, which will be used by teachers as ready-to-use materials mapped to the Qatari curriculum standards and allow them to customise and add their own materials to fit their students' needs" [11].

Knowledge Net, based on Microsoft products and implemented by ITWorx, has been described as "a three-way educational portal that connects students, parents, and teachers any time, day or night. Utilizing a unique Learning Management System, Knowledge NET provides teachers with instructional tools and resources; parents with instant access to teachers, coursework and upcoming tests; and students with the ability to communicate with peers and submit homework assignments. Knowledge Net improves content delivery, facilitates accessibility, enhances communication and expedites administrative tasks" [12].

By 2011, Qatar had made impressive gains in ICT implementation in education, with the following milestones: 93\% of primary and secondary schools in Qatar had broadband Internet access, with $98 \%$ of schools with some form of Internet access; $100 \%$ of all educators in Qatar and $96 \%$ of students could access a PC for personal or educational purposes; and $71 \%$ of $\mathrm{K}-12$ teachers had received general ICT training [13]. Another government pilot project was a specially built e-Maturity Diagnostic and Self Assessment Tool so that "Schools can evaluate their current e-maturity level, compare themselves to other schools, and develop targeted action plans to update and improve their technology" [14].

Qatar University's Continuing Education Office (CEO) signed an e-learning MoU partnership with Malomatia in 2015. Malomatia, a government technology and services provision company based in Qatar, will provide e-learning support, programmes and training for the CEO [15]. The Connected Learning Gateway (CLG) of the Egyptian-based ITWORX Education has been used throughout Qatari schools. CLG is a K-12 social media based Virtual Learning Environment that supports mobile devices [16].

E-learning has also impacted the Qatari workplace and most major companies are now using e-learning for skills upgrading (online self-paced short courses). Qatar Islamic Bank (QIB) requires all of its new employees to complete an e-learning course on operational risk to help develop a robust and vigilant risk-management culture at the bank [17].

The largest and most successful e-learning project implemented by ictQatar is the Qatar National e-Learning Portal (www.elearning.ictqatar.qa), developed by Malomatia. Offering standard Business, Nursing, Management, and IT security courses, individual courses and learning plans are accredited by such organizations as the National Association of State Boards of Accountancy, The Six Sigma Program, Board of Registered Nurses and Association for Operations Management. Technical deficits in workers in all areas of government has been widely recognized as a serious issue. Only one decade ago, many ministries recorded public data in large books by hand and many offices were not computerized. Thus the International Computer Driving License (ICDL) was a common training programme offered through online modules to government employees to teach basic computer skills. Although e-Learning Portal courses are available to any citizen or holder of a Residence Permit (RP), as of 2016 individual registration is not open, only organizational access. In a related project, Malomatia partnered with the International Human Resources Development Corporation (IHRDC) in 2015. IHRDC, a training and consulting company serving the petroleum industry, will offer workers in the oil and gas industries access to its four major e-learning libraries as well as web-based tools for assessment and competency management. Although not specifically an e-learning platform, Qatar's Hukoomi government e-portal which delivers electronic public services has propelled the nation from an international rank of 62 in 2010 to the rank of $44^{\text {th }}$ in 2014 in the United Nation's e-governance maturity and readiness survey entitled "E-Government for the Future We Want" [18].

\section{Practical And Cultural Issues}

The cost of mobile and broadband services is high since the general cost of Qatar's communications services are among the highest in the region. This may be due to the dominance of the communications company Ooredoo (formerly the national and sole carrier Q-Tel) with respect to its recent competitor Vodaphone. Broadband costs obviously limit the use of e-learning outside of school or the workplace where costs are usually subsidized by the institution. Computer literacy is increasing and no longer a serious issue 
for learners except among older adult learners as most households and all schools in Qatar have access to the Internet or Internet-enabled smart phones via data links.

Learning objects in the GCC and Qatar are often purchased from English-speaking countries; hence there is a general shortage of high quality learning objects in the Arabic language. This is a significant barrier to older Qataris past the age of 65 who did not learn English in school. Also, some materials written in Western countries may be inappropriate for the Islamic social and cultural contexts; for example, e-books or software depicting alcohol or pork consumption or inappropriate male / female interactions.

Also, many virtual learning environments employing synchronous chat flatten the classroom and reduce power differentials among students and instructors. This may not be a comfortable transition for students who are not accustomed to learning from their peers [19].

\section{CONCLUSION: Future DEVELOPMENT}

Although Internet access is available to almost all students in Qatar, in 2013 "only 37 percent of 15 - to 24 -year-olds access[ed] computers at an educational institution" [20]. This is a survey finding (see Fig. 1 below) that requires further research: for example, teachers may not yet be comfortable with technology in the classroom or they may be restricting Internet access due to student distraction from using smartphones, tablets, or smart watches in school for non-academic purposes. Although technology in schools can empower students, it can also be used for entertainment and non-academic activities, and with smaller devices such as smart watches, technology is becoming increasingly harder to monitor in the classroom. Additionally, the teacherdominated tradition of the kuttab and madrasah schools may be inhibiting young Arabic-speaking learners from developing learner autonomy which allows for the most efficient utilization of e-learning modules (motivation for learning may flag when not stimulated by the teacher). Thus integration strategies and the training and monitoring of the practices and attitudes of Qatari teachers must be ongoing to insure continuing use of the new e-learning platforms and tools available from the government.

Another challenge in Qatar is access-for-all (inclusive) education, since inclusion is a relatively new concept in the Gulf with physically and behaviorally challenged students previously being sent to specialized schools, such as schools for the blind or deaf [21]. Qatar is a signatory of the United Nations Convention on the Rights of Persons with Disabilities, thus the national e-learning and ICT strategy "commits the nation to developing an ICT-skilled population whose members share equal access to technology and can succeed in a knowledge economy. This effort includes the prioritization of disadvantaged demographic groups, especially women, retirees and citizens with special needs" [22].

Another serious concern that the government is attempting to address through campaigns and its security programs led by Q-Cert is online privacy, confidentiality, and security. Private and legally protected student data stored in the cloud such as grades and health records may be vulnerable to internal misuse, sale to third parties without adequate consent, or hacking [23]. Privacy is particularly important in the Qatari society as the revealing of private family matters on social media and the inappropriate use of photographs (doctoring of images in Photoshop by malicious persons to make them obscene or blasphemous) can have grave consequences for individuals, such as ostracization (shunning) [24]. In a 2013 survey of households and individuals in Qatar, only 0-1\% of Qataris, including both the young and the old, said that they felt safe online due to malware, viruses, phishing, information and identity theft, etc. (See Fig. 2 below).

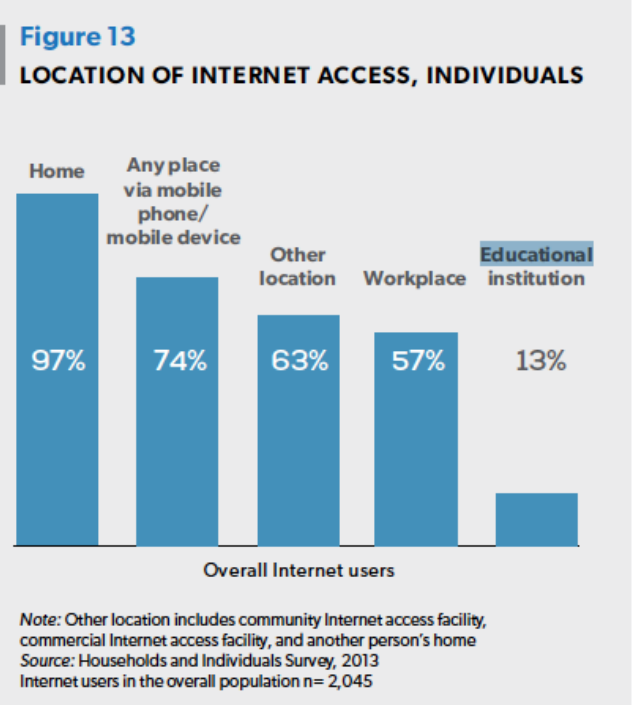

Source $=$ Qatar's ICT Landscape 2014: Households and Individuals. Fig. 1. Individuals' location access of Internet, Qatar national survey, 2013.

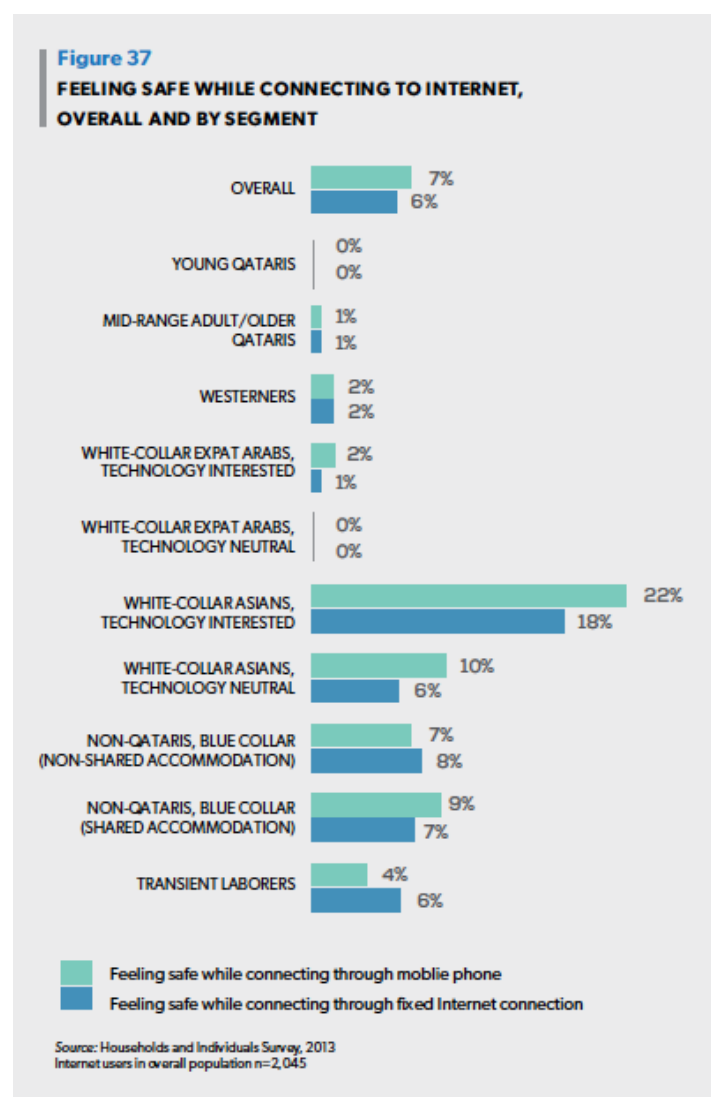

Source $=$ Qatar's ICT landscape 2014: Households and individuals . Fig. 2. Feeling safe while connected to the Internet, Qatar national survey, 2013. 
E-learning in Qatar has experienced unprecedented growth, paralleling other areas of rapid development such as the establishment of a Broadband network in the last ten years, the end of Q-tel's decades-long monopoly on communication markets, which has led to competition and lower prices for services, and the increasing use of all forms of technology in classrooms, including the nationwide K-Net platform. Unfortunately, only a few outcomes assessments have been performed (measuring the actual impact that e-learning is having on skills and knowledge) possibly due to other priority projects such as basic infrastructural development and healthcare improvements. Due to the rapid population growth, the public health system is currently overwhelmed.

\section{ACKNOWLEDGMENT}

The author would like to thank the Ministry of Information and Communications Technology (ictQATAR) in the State of Qatar for use of their government white papers and reports. The librarians Carol Ann Nonino, Sally Birch, and Ross MacDonald of the Delib library at Weill Cornell Medicine in Qatar provided invaluable assistance in a systematic review of the available peer reviewed literature. Colleagues in the Premedical Department of Weill Cornell Medicine in Qatar graciously offered editorial suggestions on an early draft of this work. The author would also like to thank Sihem Hamlaoui for locating hard to obtain grey literature on e-learning in Qatar.

\section{REFERENCES}

[1] I. Ibrahim and F. Harrigan, "Qatar's economy: Past, present and future," QScience Connect, 2012, vol. 9, pp. 1-24.

[2] A. Fromherz, Qatar: A Modern History, London: I.B. Tauris, 2012, pp 17-20.

[3] CIA World Factbook. (October 2016). Population: Qatar. [Online]. Available: https://www.cia.gov

[4] A. J. Kobaisi, "The development of education in Qatar, 1950-1977 with an analysis of some educational problems," PhD thesis, Univ. Durham, Durham, UK, 1979, p. 31.

[5] Reuters. (November 2016). Qatar worker complaints fall since start of electronic wage payments. [Online]. Available: http://www.reuters.com/article/us-qatar-labour-reform-idUSKBN12X 115

[6] A. S. Weber, "Revolution in Arabian gulf education," in $\mathrm{N}$ Bakić-Mirić \& D. Gaipov, Ed., Current Trends and Issues in Higher Education: An International Dialogue, Cambridge: Cambridge Scholars Press, 2016, pp. 141-156.

[7] Qatar National Vision 2030, Doha: General Secretariat for Development Planning (GSDP), 2008.

[8] Qatar National Vision 2030. Doha: General Secretariat for Development Planning (GSDP), 2008, p. 13.

[9] General Secretariat for Development Planning (GSDP), The Qatar National Development Strategy 2011-2016 (QNDS), 2011, Doha: QNDS, p. 130.

[10] General Secretariat for Development Planning (GSDP). The Qatar National Development Strategy 2011-2016 (QNDS), 2011, Doha: QNDS, pp. 130-131.
[11] Gulf Times. (September 2006). E-learning project starts at girls' school in Wakrah. [Online]. Available: http://www.gulf-times.com/

[12] ictQatar. (January 2011). Knowledge Net. supreme council of information and communication technology. [Online]. Available: http://www.ictqatar.qa/output/page442.asp

[13] ictQatar, Qatar's ICT Landscape 2011, Doha: ictQatar, 2011.

[14] ictQatar. Qatar's National Digital Plan 2015: Advancing the Digital Agenda, Doha: ictQatar, 2011, p. 40.

[15] Gulf Times. (September 2015). QU, Malomatia sign collaborative agreement. [Online]. Available: http://www.gulf-times.com/

[16] Qatar Tribune. (Feb 2015). E-learning a growing trend in Qatar's classrooms. [Online]. Available: www.qatar-tribune.com

[17] Gulf Times. (June 2015). QIB e-learning for employees focuses on operational risks. [Online]. Available: http://www.gulf-times.com/

[18] The United Nations (U.N.) E-government survey 2014: E-government for the future we want. [Online]. Available: http://unpan3.un.org/egovkb/Portals/egovkb/Documents/un/2014-Sur vey/E-Gov_Complete_Survey-2014.pdf

[19] A. S. Weber, "Sociocultural dimensions of e-learning in emerging nations," in Proc. 2014 International Conference on Advances in ICT for Emerging Regions (ICTer) Conference Proceedings, Colombo, Sri Lanka: IEEE, p. 254.

[20] ictQatar, Qatar's ICT Landscape 2014: Households and Individuals, Doha: ictQatar, 2015.

[21] A. S. Weber. "Inclusive education in the gulf cooperation Council," in Proc. 3rd International Conference on New Trends in Education and Their Implications, 2012, pp. 345-57.

[22] ictQatar, Qatar's eAccessibility Policy, Doha: ictQatar, 2011, p. 6.

[23] A. S. Weber, "Cloud computing in education," in Ubiquitous and Mobile Learning in the Digital Age, D. Sampson, P. Isaias, D. Ifenthaler, and M.J. Spector, Ed. New York: Springer, 2012, pp. 19-36.

[24] A. S. Weber. Web-Based Learning in Qatar and the GCC States, Doha: Center for International and Regional Studies (CIRS), pp. 9-10.

Alan S. Weber has taught medical humanities (literature, philosophy, history) since 2006 at Weill Cornell Medicine-Qatar, a satellite campus of Cornell University in the Middle East. He previously taught languages, literature, and the history of science and medicine at Cornell University and he served as an editor of the history of science journal Isis (U. Chicago Press). His course "Electronic Shakespeare" was one of the first entirely online courses offered in the state of New York at the State University of New York at Binghamton in 1996. His recent publications related to e-learning include: Bennett, E. and A.S. Weber. (2015). Cloud computing in New York State education: Case study of failed technology adoption of a statewide longitudinal database for student data. QScience Connect, 2015(1), n.p. doi: 10.5339/connect.2015.2; Weber, A.S. (2016). Strategic planning for cloud computing adoption in STEM education: Finding best practice solutions. In L. Chao (Ed.), Handbook of research on cloud-based STEM education for improved learning outcomes (pp. 1-11). Hershey, PA Information Science Reference. doi:10.4018/978-1-4666-9924-3.ch001; Weber, A.S. (2015). Use of cloud-based graphic narrative software in medical ethics teaching. In M.B. Nunes \& M. Mcpherson (Eds.), MCCSIS conference (pp. 167-72). Gran Canaria, Spain: IADIS; Weber, A. S. (2014). Sociocultural dimensions of e-learning in emerging nations. In 2014 International Conference on Advances in ICT for Emerging Regions (ICTer) conference proceedings (p. 254). Colombo, Sri Lanka: IEEE; Weber, A.S Suggested legal framework for student data privacy in the age of big data and smart devices (2014). In: R. Neves-Silva, G.A. Tsihrintzis, V. Uskov, R.J. Howlett, L.C. Jain, (Eds.), Smart digital futures (pp. 669-78). Amsterdam: IOS Press. (Frontiers in artificial intelligence and applications, vol. 262). He is the editor-in-chief of The Handbook of E-learning in the MENA Region (forthcoming, 2017). 